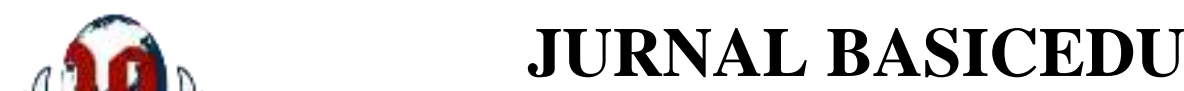

Volume 6 Nomor 1 Tahun 2022 Halaman 1341 - 1349

Research \& Learning in Elementary Education

https://jbasic.org/index.php/basicedu

https:/lbasic.org/index.php/basicedu

\title{
Pengembangan Media Pembelajaran IPA dengan Menggunakan Media "Rumah Eksis" di Sekolah Dasar
}

\author{
Vivi Herawati ${ }^{1 凶}$ \\ Pendidikan Guru Madrasah Ibtidaiyah, Universitas Islam Negeri Sumatera Utara, Indonesia \\ E-mail: Viviiherawati@gmail.com
}

\begin{abstract}
Abstrak
Di dalam penelitian ini dilatarbelakangi oleh adanya faktor yaitu kurangnya suatu media pembelajaran yang digunakan dalam materi pembelajaran IPA di SD Swasta Bakti Luhur Kecamatan Medan Helvetia. Dalam hal ini peneliti ingin mengembangkan sebuah media pembelajaran berupa media Rumah Eksis (Edukasi Metamorfosis). Prosedur yang akan digunakan dalam penelitian ini yaitu dengan menggunakan prosedur penelitian R\&D. Subyek yang digunakan dalam penelitian ini dilakukan di Sekolah Dasar Swasta Bakti Luhur. Tujuan yang ada di dalam penelitian ini yaitu mendeskripsikan serta menerapkan suatu konsep pembuatan media pembelajaran rumah eksis materi Metamorfosis di SD IV Swasta Bakti Luhur. Langkahlangkah dalam penelitian yaitu menganalisis atau menjelaskan kebutuhan dan kepribadian siswa, menentukan suatu tujuan dalam belajar mengajar, merangkum suatu materi pembelajaran, mengembangkan suatu alat ukur keberhasilan, pra produksi (desain produk awal), produksi dan pasca produksi diadaptasi dari Sadiman. Hasil persentase dari kelulusan peserta didik dalam pembelajaran mengenai IPA dalam materi metamorfosis dengan menggunakan media Rumah Eksis menunjukkan peningkatan yaitu 20\%. Disimpulkan bahwa media ini lebih efektif bila digunakan dalam mempelajari metamorfosis menggunakan media rumah eksis.
\end{abstract}

Kata Kunci: Media Pembelajaran, Rumah Eksis, Metamorfosis.

\begin{abstract}
This research is motivated by a factor, namely the lack of a learning media used in science learning materials at SD Swasta Bakti Luhur, Medan Helvetia District. In this case, the researcher wants to develop a learning media in the form of the Existing House (Metamorphosis Education) media. The procedure that will be used in this research is to use $R \& D$ research procedures. The subjects used in this study were conducted at Bakti Luhur Private Elementary School. The purpose of this study is to describe and apply a concept of making home learning media with Metamorphosis material in SD IV Swasta Bakti Luhur. The steps in the research are analyzing or explaining the needs and personality of students, determining a goal in teaching and learning, summarizing a learning material, developing a measuring instrument for success, pre-production (initial product design), production and post-production adapted from Sadiman. The results of the percentage of students' graduation in learning about science in metamorphosis material using the Existing House media showed an increase of 20\%. It was concluded that this media was more effective when used in studying metamorphosis using existing home media.
\end{abstract}

Keywords:Learning Media, Existing Home, Metamorphosis.

Copyright (c) 2022 Vivi Herawati

$\triangle$ Corresponding author :

Email : Viviiherawati@gmail.com

DOI : https://doi.org/10.31004/basicedu.v6i1.2297

ISSN 2580-3735 (Media Cetak)

ISSN 2580-1147 (Media Online)

Jurnal Basicedu Vol 6 No 1 Tahun 2022

p-ISSN 2580-3735 e-ISSN 2580-1147 
1342 Pengembangan Media Pembelajaran IPA dengan Menggunakan Media "Rumah Eksis"di Sekolah Dasar - Vivi Herawati

DOI: https://doi.org/10.31004/basicedu.v6i1.2297

\section{PENDAHULUAN}

Dolong mengemukakan bahwa pembelajaran adalah perpaduan antara materi, fasilitas, peralatan, dan prosedur yang mempengaruhi tujuan pembelajaran. Dalam pembelajaran di sekolah dasar maupun madrasah ibtidaiyyah terdapat ada beberapa mata pelajaran yang belajarnya itu harus di dalam kelas serta belajar di luar kelas (outdor), salah satu materi pembelajaran itu adalah IPA yang bukan hanya sekedar sebuah materi, tetapi juga praktik. Oleh karena itu perlu dipahami bahwa ilmu pengetahuan alam (IPA) merupakan suatu konsep pembelajaran alam yang memiliki suatu hubungan yang sangat luas dengan kehidupan manusia. Pembelajaran IPA di sekolah dasar yaitu sebuah proses pembelajaran yang menekankan pada suatu pembelajaran ataupun pemahaman mengenai pengalaman langsung kepada anak didik untuk menumbuh kembangkan kemampuan dalam mengeksplorasi serta memahami lingkungan alam secara alami(Dolong, 2016). Menurut mendikbud yang terdapat di dalam jurnal annisa, menyatakan bahwa pembelajaran merupakan suatu proses interaksi antara peserta didik dengan sumber belajar pada suatu lingkungan belajar. (Annisa \& Simbolon, 2018) Skinner dalam Dimyati menjelaskan bahwa belajar merupakan suatu perilaku, disaat orang belajar maka responnya menjadi lebih baik. Begitu juga sebaliknya jika tidak belajar maka responnya akan menurun. (Tarwiti, C., \& Wijayanti, 2018). Menurut Sumiati dan Asra, bahwa hasil belajar merupakan "perubahan perilaku" perilaku ini mencakup hal-hal yang berkaitan dengan pengetahuan pemahaman, keterampilan, sikap, kemampuan berfikir, penghargaan terhadap suatu permasalahan yang sedang dihadapi (Ananda, 2017). Di dalam perkembangan teknologi turut serta ikut andil dalam mengubah suata gaya belajar terkhusus mengenai pemanfaatan sebuah media pembelajaran. (Peprizal \& Syah, 2020). Menurut Mustafa dalam wahyu ningtiyas menyatakan bahwa pencapaian sebuah hasil belajar IPA di Indonesia saat ini tergolong rendah yang dipengaruhi oleh beberapa faktor (Wahyu Ningtiyas \& Mei, 2019). Jadi dapat disimpulkan bahwa pembelajaran IPA bertujuan untuk memenuhi harapan serta tujuan Kurikulum Tingkat Satuan Pendidikan (KTSP), adalah di dalam pembelajaran harus ada tentang mendidik, intelektual, merangsang aktivitas serta kreativitas anak, efektif, demokratis, menarik dan merangsang. Namun kenyataannya di Indonesia, karena kurangnya tenaga pendidik yang menerapkan konsep ilmiah, materi atau mata kuliah, fasilitas, dan media pembelajaran siswa, maka kebutuhan akan mata pelajaran IPA tidak banyak diminati dan kurang mendapat perhatian.

Menurut Hamid dalam Chika, menyatakan bahwa suatu pendidikan merupakan suatu hal yang begitu sangat penting serta kebutuhan bagi setiap manusia didalam kehidupannya. (Chika Pratama, 2019). Menurut khoiriyah, dia berpendapat bahwa IPA merupakan suatu ilmu pengetahuan secara teoritis yang didapat serta disusun melalui cara yang khusus, yaitu meliputi dengan melakukan sebuah observasi eksperimental, menyimpulkan, penyusunan materi, eksperimentasi, observasi dan demikian seterusnya. (Khoiriyah \& Sari, 2018) adapun pendapat Djumhana dalam jurnal priliza yang mengemukakan bahwa IPA adalah ilmu yang berhubungan tentang gejala-gejala alam yang disusun secara sistematis dan teratur, berlaku secara umum berupa hasil observasi serta eksperimen. (Prilliza et al., 2020) Putra dalam veronica berpendapat bahwa Pembelajaran IPA di sekolah dasar sebaiknya memberikan kebebasan para peserta didik dalam membuat suatu ide ataupun sebuah penafsiran pada suatu hal dalam sebuah kegiatan pembelajaran untuk merancang serta menemukan sesuatu secara mandiri. (Veronica et al., 2018) adapun menurut susanto dalam widiana yang berpendapat bahwa IPA merupakan sebuah usaha manusia dalam memahami serta mempelajari ilmu alam semesta melalui sebuah pengamatan yang tepat terhadap sasaran serta menggunakan berbagai prosedur yang dijelaskan juga dengan suatu penalaran maupun pemahaman sehingga mendapatkan hasil atau sebuah kesimpulan. (Widiana et al., 2019).

Mariani dalam Qistina mengemukakan bahwa di dalam sebuah pengembangan suatu media pembelajaran sangat perlu dilakukan secara terus menerus, mengikuti kebutuhan minat dan bakat siswa. (Masturah et al., 2018) Media pembelajaran merupakan sebuah teknologi yang membawa sebuah pesan atau 
1343 Pengembangan Media Pembelajaran IPA dengan Menggunakan Media "Rumah Eksis"di Sekolah Dasar - Vivi Herawati

DOI: https://doi.org/10.31004/basicedu.v6i1.2297

informasi yang bisa dimanfaatkan untuk kepentingan pembelajaran dalam proses belajar secara efisien dan efektif. (Qistina et al., 2019). Aquami menyatakan bahwa penggunaan sebuah teknologi dalam suatu kegiatan pembelajaran di kelas sesungguhnya memiliki kelebihan yaitukinerja peserta didikmenjadi lebih cepat dan mudah. (Aquami et al., 2019) Rusman dalam Suryani menjelaskan bahwa guru dapat memilih serta menggunakan suatu media pembelajaran yang tepat dan sesuai dengan tujuan pembelajaran. (Suryani et al., 2018)Widdiharto dalam Alfiyah mengemukakan bahwasannya kesulitan belajar yaitu kurangnya keberhasilan peserta didik dalam menguasai atau memahami suatu konsep, struktur atau prinsip untuk menyelesaikan berbagai masalah pada materi tersebut. (Alfiyah et al., 2021)Kristantomenjelaskan bahwasannya media pembelajaran merupakan segala sesuatu ataupun sebuah hal yang dapat menyampaikan informasi dan dapat dimodifikasi, dilihat, didengar, dibaca atau didiskusikan untuk merangsang suatu pikiran, minat atau bakat, perhatian, serta emosi siswa yang ada didalam sebuah kegiatan proses pembelajaran untuk mencapai suatu tujuan pembelajaran.(NURDIANA, 2018).

Ada beberapa problematika ataupun permasalahan yang sedang dihadapi ataupun dilalui dalam dunia pendidikan pada saat ini yaitu pendidik tidak melaksanakan proses pembelajaran yang diterapkan dengan baik. Ketika melakukan suatu proses pembelajaran di sekolah, peserta didik hanya bertujuan melalui kemampuan mengingat suatu informasi yang berbeda tanpa mengharuskan siswa untuk memahami suatu ilmu serta menerapkan berbagai informasi tersebut dalam kehidupan sehari-hari. Menurut Rozie, masalah yang sedang dihadapi saat ini ada yang berasal melalui guru yang ada di sekolah, dijelaskan bahwa di dalam suatu proses pembelajaran seorang guru hanya meminta peserta didik untuk menghafalnya saja tanpa memahami atau menerapkannya dalam kegiatan pembelajaran siswa di kehidupan sehari-hari. Oleh karena itu, peneliti memahami bahwa peserta didik hanya memiliki kemampuan menghafal suatu ilmu pembelajaran tanpa memahami serta menerapkannya di kehidupan sehari hari.Siswalah yang sebenarnya merevisi suatu ilmu di dalam pemahamannya tentang materi IPA. Peran dari seorang guru dalam suatu proses pembelajaran yaitu sebagai moderator, motivator dan fasilitator. Wulandari juga berpendapat bahwa seorang guru hanya dapat melihat serta memantau proses suatu perubahan ilmu pengetahuan dalam benak peserta didik melalui perannya dalam mempersiapkan suatu media pembelajaran. Agar siswa memiliki pemahaman yang lebih tinggi dan lebih sempurna dari pengetahuan yang ada. Dari pernyataan tersebut maka peneliti dapat menyimpulkan bahwasannya seorang guru hanya dapat memberikan sebuah gambaran maupun pengembangan serta ilmu pengetahuan. Karena dalam ilmu teknologi yang ada pada saat ini sudah begitu banyak yang berkembang, begitu pula anak-anak sudah tidak asing lagi dengan teknologi yang canggih.

Menurut Haryono, ketika mengkaji masalah pembelajaran di bidang IPA, peserta didik yang belajar di sekolah tidak terbiasa menggunakan pemahamannya tetapi terbiasa dengan suatu metode menghafal, mereka fokus hanya pada sumber standar pemahaman serta ilmu yang diajarkan oleh gurunya di kelas selama pembelajaran berlangsung. Disini dapat dilihat saat pembelajaran yang dilakukan di dalam kelas maupun pembelajaran yang dilakukan di lingkungan atau luar kelas dalam kehidupan sehari-hari. Menurut pernyataan di atas, peneliti dapat menyimpulkan bahwa di dalam suatu materi pembelajaran saintifik, orang lebih menekankan untuk menggunakan kemampuan nalarnya atau daya pikirnya untuk berpikir kritis tentang suatu masalah yang dihadapinya dan peserta didik juga boleh menerapkan beberapa materi yang sudah dipelajari di dalam kelas maupun luar kelas sehingga tidak ada kesenjangan antara materi pembelajaran yang dilakukan di dalam kelas maupun di luar kelas atau lingkungan sehari-hari.Rawungmenyatakan bahwasannya di dalam suatu proses materi pembelajaran yang akan dilakukan di dalam kelas memiliki hubungan yang sangat erat antara pendidik dengan peserta didik yaitu guru dengan siswa, kurikulum, sarana serta prasarana. Di dalam suatu proses pembelajaran seorang guru hanya dapat memilih suatu strategi pembelajaran yang tepat dan cocok berdasarkan materi yang disajikan dalam suatu proses pembelajaran sebagai tujuan untuk mencapai suatu tujuan pembelajaran(Rawung, 2019). Pane menyatakan bahwa dalam suatu kegiatan pembelajaran yang dilakukan oleh dua mata pelajaran yaitu pendidik dengan peserta didik serta perilaku guru dengan perilaku 
1344 Pengembangan Media Pembelajaran IPA dengan Menggunakan Media "Rumah Eksis"di Sekolah Dasar - Vivi Herawati

DOI: https://doi.org/10.31004/basicedu.v6i1.2297

siswa. Jadi dapat disimpulkan oleh peneliti bahwa pada dasarnya belajar adalah suatu prose kegiatan berencana yang bertujuan untuk memfasilitasi atau merangsang seorang pelajar yang baik.(Isdayanti et al., 2020).

Menurut jurnal penelitian yang dilakukan oleh Lado, hanya menyatakan tentang pengenalan suatu materi metamorfosis sempurna dan metamorfosis tidak sempurna(Lado \& Rosanensi, 2020), tanpa menjelaskan perbedaan dari metamorfosis sempurna dengan metamorfosis tidak sempurna ataupun mendeskripsikan tahap demi tahap siklus hidup hewan misalnya kupu-kupu dan belalang.

Berdasarkan wawancara yang peneliti lakukan pada tanggal 1 November 2021 dengan guru kelas IV SD Swasta Bakti luhur Medan Helvetia pada tahun ajaran 2021/2022 terdapat permasalahan dalam kegiatan proses pembelajaran yaitu siswa kurang paham dan tidak peduli tentang siklus hidup hewan mengenai materi metamorfosis, kurangnya konsentrasi siswa dalam pembelajaran sehingga siswa kesulitan untuk memahami materi. Hal tersebut dapat dilihat melalui proses pembelajaran peserta didik di kelas serta kurangnya media pembelajaran guru untuk mendukung proses pembelajaran selama pembelajaran berlangsung. Maka yang diperlukan yaitu sebuah media pembelajaran yang memiliki tampilan menarik karena peserta didik masih membutuhkan benda yang menarik, konkrit serta bagus untuk menarik perhatian siswa sesuai dengan materi yang diajarkan. Berdasarkan hasil wawancara di atas, peneliti berfikir untuk mengembangkan sebuah penelitian media pembelajaran dengan pengembangan media Rumah Eksis untuk siswa kelas IV SD Swasta Bakti Luhur. Sesuai denganrumusan dari pertanyaan dalam penelitian ini adalah konsep pembuatan Media Rumah Eksis pada pembelajaran IPA kelas IV, dan seberapa efektif media Rumah Eksis untuk siswa kelas IV SD.

Keunggulan produk media Rumah Eksis adalah desain media bukan seperti kotak biasanya. Rumah Eksis yang dibuat menggunakan kertas duplex yang dibentuk seperti rumah dan isinya itu terdapat materi serta games pembelajaran untuk peserta didik agar tidak bosan selama pembelajaran berlangsung.Manfaat yang terdapat di dalam penelitian ini yaitu dapat menciptakan gagasan baru mengenai pengembangan sebuah media yang bermanfaat bagi peserta didik dalam proses pembelajaran di sekolah dasar. Melalui media pembelajaran Rumah Eksisdapat membantu siswa memahami daur hidup hewan, serta meningkatkan motivasi belajar dan pengetahuan ilmiahnya lebih baik sehingga mencapai nilai KKM.

\section{METODE}

Metode penelitian yang diambil penelitiuntuk digunakan di dalam penelitian ini yaitu menggunakan metode penelitian research and development $(R \& D)$, yang dapat diartikan bahwa penelitian itu sebagai suatu penelitian serta sebuah pengembangan dalam media pembelajaran. Metodologi R\&D dapat dipahami sebagai metode ilmiah untuk meneliti, merancang, dan memvalidasi produk akhir(Koriaty \& Agustani, 2016). Untuk penelitian ini, dilihat bahwasannya produk ataupun media yang akan dikembangkan oleh peneliti di dalam penelitian ini merupakan produk yang sudah ada maka termasuk dalam R\&D level 3, maka peneliti mengembangkan suatu produk dengan menggunakan konsep berdasarkan kepribadian peserta didik dan beberapa permasalahan yang ada di SD Swasta Bakti Luhur Kota Medan. Oleh karena itu, laporan penelitian ini memuat data-data yang menggambarkan penyajiannya. Melalui penelitian ini, peneliti akan mengkaji sebuah permasalahan yang ada pada siswa di SD Swasta Bakti Luhur Kota Medan, bagaimana konsep dan aplikasi media dalam negeri yang berkembang pada saat ini.

Objek penelitian di lakukan di SD Swasta Bakti Luhur Kecamatan Medan Helvetia Kota Medan dan siswa kelas IV SD Swasta bakti Luhur Kecamatan Medan Helvetia. Sumber data yang terdapat di dalam sebuah penelitian ini menggunakan 2 sumber yaitu menggunakan beberapa sumber data kata serta tindakan ataupun evaluasi dari beberapa Guru ahli serta peserta didik di SD Swasta Bakti Luhur dan melalui sumber data tertulis serta buku-buku sekolah yang relevan untuk dijadikan referensi. Validasi yang diambil oleh 
1345 Pengembangan Media Pembelajaran IPA dengan Menggunakan Media "Rumah Eksis"di Sekolah Dasar - Vivi Herawati

DOI: https://doi.org/10.31004/basicedu.v6i1.2297

peneliti di dalam penelitian ini ada dalam 2 hal yaitu menggunakan validasi media yang akan dilakukan oleh 2 ahli materi serta menggunakan validasi konstruk yang dilakukan pada Guru Seni Rupa dan IPA di kelas IV SD Swasta Bakti Luhur Kecamatan Medan Helvetia. Teknik yang akan dilakukan oleh peneliti yaitu dengan menggunakan beberapa teknik, ada yang menggunakan teknik observasi, wawancara, kuisioner serta teknik gabungan ketiganya.

Langkah-langkah di dalam penelitian R\&D yang dilakukan oleh peneliti dalam suatu penelitian ini diadaptasi melalui langkah Sugiono. Langkah-langkah tersebut meliputi riset terhadap suatu produk yang sudah ada. Kunjungan lapangan serta pengembangan suatu produk, verifikasi ahli, evaluasi media, uji kelayakan media, evaluasi media implementasi produk dan hasil akhir. Di dalam metode penelitian R\&D dengan skala besar maupun menggunkaan semua prosedur maka tahapannya akan membutuhkan waktu yang relative cukup lama dan biaya yang relative cukup banyak. Sedangkan dalam pengembangan suatu media pembelajaran di penelitian ini diadaptasi melauli teori yang disampaikan oleh Sudirman dalam marsudi bahwalangkah-langkah tersebut yaitu meliputi tentang menganalisis suatu kebutuhan serta kepribadian peserta didik, mengembangkan suatu materi dalam pembelajaran, dan mengembangkan sebuah alat untuk mengukur keberhasilan dalam proses praproduksi hingga pascaproduksi(Purnama \& Marsudi, 2017).

\section{HASIL DAN PEMBAHASAN}

\section{Hasil Penelitian Produk yang Telah Ada}

Gurumenggunakan Media saat pembelajaran berlangsung di SD Swasta Bakti Luhur yaitu menggunakan contoh gambar daur hidup hewan yang dipresentasikan di depan kelas. Pada saat yang sama dijelaskan juga langkah-langkahnya dengan menggunakan metode demonstrasi di papan tulis yang dilakukan saat pembelajaran berlangsung.

\section{Konsep Perancangan Rumah Eksis Untuk Media Pembelajaran IPA SD Swasta Bakti Luhur}

Tema Media Rumah Eksis adalah Metamorfosis pada hewan yaitu kupu-kupu dan belalang.

\section{Penentuan Gambar}

Gambar-gambar pada kotak edukasi adalah gambar metamorfosis kupu-kupu dan belalang. pembuatan gambar yang diambil dari Google kemudiandicetak. Setelah itu, disesuaikan gambar dengan materi metamorfosis serta dipadukan dengan gamesuga (mengurutkan gambar) dan tega (tebak gambar) agar lebih menarik dan membuat belajar itu menyenangkan.

\section{Langkah-langkah Perancangan Rumah Eksis Untuk Media Pembelajaran IPA Menganalisis Kebutuhan Siswa dan Karakteristik Siswa}

Langkah-langkah yang diambil oleh peneliti dalam mengembangkan suatu media pembelajaran adalah memahami apa yang dibutuhkan oleh siswa atau peserta didik. Karena pada dasarnya setiap kelompok siswa maupun per individu pasti memiliki kebutuhan yang berbeda-beda. Jadi dapat disimpulkan oleh peneliti bahwa di dalam penelitian ini, untuk menganalisis suatu kebutuhan siswa atau peerta didik, peneliti menggunakan teknik pengumpulan data yaitu berupa angket.

\section{Merumuskan Tujuan Instruksional Pembelajaran}

SD Swasta Bakti Luhur Kecamatan Medan Helvetia menggunakan kurikulum K13. Sehingga pada tahap ini, perumusan tujuan pembelajaran yaitu agar memiliki kemampuan untuk produktif, kreaktif, inovatif, dan efektif.

\section{Merumuskan Materi Pembelajaran}

Setelah merumuskan tujuan pembelajaran yang telah dibentuk, langkah selanjutnya adalah membentuk bahan ajar ataupun materi pembelajaran yang disusun melalui RPP. Seperti penelitian ini, materi pembelajaran mengalami tambahan yaitu media pembelajaran. Jadi dalam hal ini, untuk isi bahan ajar dapat meliputi oleh 
1346 Pengembangan Media Pembelajaran IPA dengan Menggunakan Media "Rumah Eksis"di Sekolah Dasar - Vivi Herawati

DOI: https://doi.org/10.31004/basicedu.v6i1.2297

suatu tujuan pembelajaran yang akan dicapai oleh peserta didik setelah menyelesaikan sebuah kegiatan proses pembelajaran sesuai dengan RPP. Materi yang digunakan oleh peneliti dalam Media Rumah Eksis adalah konsep metamorfosis, materi serta penjelasan metamorfosis sempurna, metamorfosis tidak sempurna, metamorfosis kupu-kupu dan metamorfosis belalang.

\section{Mengembangkan Alat Pengukuran Keberhasilan}

Dalam mengembangkan alat pengukuran untuk keberhasilan, maka siswa dituntut untuk berkontribusi dalam pembelajaran berlangsung menggunakan media rumah eksis dan mengerjakan pre test dan post test.

\section{Desain Awal Produk Prapoduksi (Sinopsis)}

Materi yang dijelaskan oleh peneliti di dalam media rumah eksis ini ada 5 yaitu:

1. Materi pertama yang berisi tentang penjelasan atau pengertian dari metamorfosis, metamorfosis sempurna dan tidak sempurna.

2. Materi kedua yang berisi mengenai sedikit penjelasan metamorfosis sempurna (kupu-kupu).

3. Materi ketiga yang berisi tentang beberapa penjelasan konsep metamorfosis tidak sempurna (belalang)

4. Materi yang berisi tentang menebak gambar gambar metamorfosis sempurna dan tidak sempurna yang sudah disediakan.

5. Materi yang berisi tentang mengurutkan daur hidup hewan mengenai metamorfosis sempurna dan tidak sempurna.

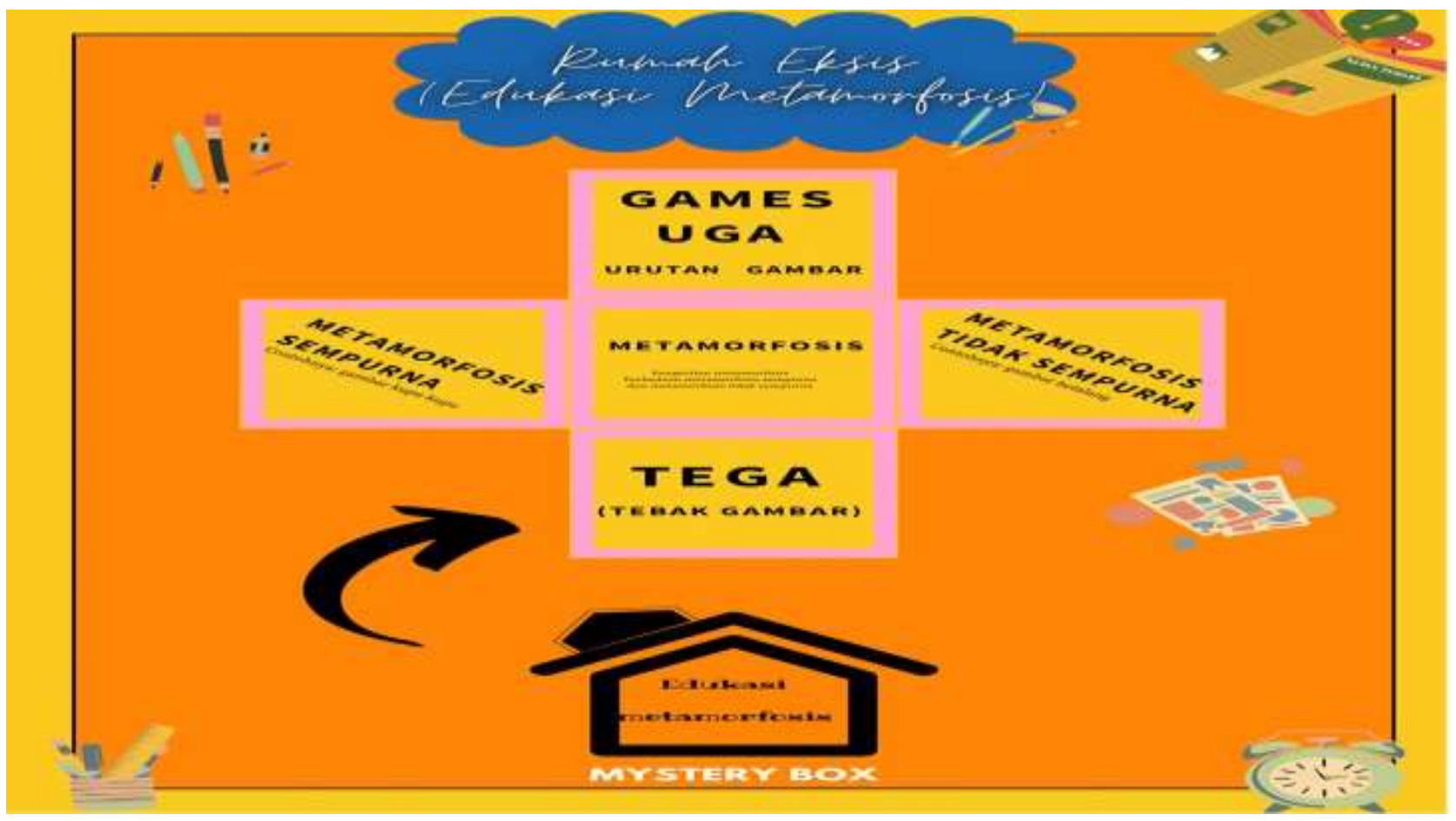

Ket: Sketsa Media Rumah Eksis (dibuat mengguanakan Canva)

Media Rumah Eksis ini dirancang se-menarik mungkin agar siswa dapat lebih memahami materi tentang metamorfosis.

\section{Produksi}

ProsesProduksi dalam pembuatan media dilakukan di Medan serta di rumah peneliti sendiri pada tanggal 14 s/d 20 November 2021

\section{Pascaproduksi}

Proses Editing media ataupun konsep digital yaitu dilakukan peneliti sendiri dengan menggunakan software program canva melalui handphone Samsung a12. 
1347 Pengembangan Media Pembelajaran IPA dengan Menggunakan Media "Rumah Eksis"di Sekolah Dasar - Vivi Herawati

DOI: https://doi.org/10.31004/basicedu.v6i1.2297

\section{Mengadakan Validasi dan Revisi Media}

Kegiatan dalam memvalidasi media yang sudah dilakukan oleh beberapa para ahli untuk mengumpulkan kritik maupun saran bagi suatu pengembangan buku ajar atau media pembelajaran yang dirancang. Dalam penelitian ini, sertifikasi dilakukan pada dua hal, yaitu verifikasi media dan verifikasi materi. Verifikasi media dilakukan oleh 2 orang ahli komunikasi yaitu wali kelas IV dan V. Sedangkan verifikasi materi dilakukan oleh guru kelas IV SD Swasta Bakti Luhur karena dianggap guru yang lebih faham media.

\section{Pengaruh Penerapan Media Rumah Eksis dalam Pembelajaran IPA Uji Coba Penerapan Produk di Sekolah}

Dalam hal uji coba pengaplikasian produk ataupun media dilakukan dua kali seminggu di Kelas IVA SD Swasta Bakti Luhur pada pukul WIB pada tanggal 1 Desember 2021 dan 3 Desember 2021 mulai pukul 13.00 hingga 15.00. Hasil belajar siswa Rumah Eksis dengan media lebih tinggi dari 85\%- 65\% siswa tanpa media. Oleh karena itu, dampak penggunaan media adalah 20\%.Media pembelajaran rumah eksis sudah efektif digunakan dalam pembelajaran walaupun kurangnya aplikasi seperti teknologi yang sudah canggih karena adanya keterbatasan fasilitas yang ada di sekolah. Dijelaskan dengan dihasilkannya kelayakan pengembangan produk media rumah eksis yang digunakan oleh kelas IV SD dalam pembelajaran IPA materi metamorfosis yaitu memenuhi kriteria praktis, valid, serta efektif. Terdapat kesesuaian pada kelayakan sebuah media pembelajaran seperti yang dibuat oleh Tarwiti di dalam penelitiannya bahwa adanya peningkatan hasil belajar siswa melalui media pembelajaran kotak ajaib mengenai materi pesawat sederhana. (Tarwiti, C., \& Wijayanti, 2018).

\section{KESIMPULAN}

Berdasarkan hasil penelitian, Hasil persentase siswa yang lulus materi pembelajaran IPA mengenai metamorfosis dengan menggunakan media Rumah Eksis menunjukkan bahwa terjadi peningkatan persentase siswa yang lulus materi pembelajaran IPA tanpa menggunakan media pembelajaran Itu berkisar $20 \%$ dalam Materi Rumah Eksis Metamorfosis untuk digunakan di Kelas IV SD Swasta Bakti Luhur Kecamatan Medan Helvetia agar media lebih efektif dan praktis saat digunakan dalam pembelajaran IPA.

\section{UCAPAN TERIMA KASIH}

Saya mengucapkan syukur Alhamdulillah kepada Allah SWT, dan banyak terimakasih kepada Dr. Sapri, S.Ag, MAdan Dr. Zaini Dahlan, M.Pd.I selaku dosen pembimbing yang telah membantu selama pengerjaan artikel jurnal, serta terimakasih juga kepada keluarga terkhusus orang tua, abang dan kakak. danterima kasih kepada teman-teman terdekat saya yang telah memberikan dukungan selama pengerjaan artikel jurnal.

\section{DAFTAR PUSTAKA}

Alfiyah, Z. N., Hartatik, S., Nafiah, N., \& Sunanto, S. (2021). Analisis Kesulitan Belajar Matematika Secara Daring Bagi Siswa Sekolah Dasar. Jurnal Basicedu, 5(5), 3158-3166. Https://Doi.Org/10.31004/Basicedu.V5i5.1297

Ananda, R. (2017). Penggunaan Media Audio Visual Untuk Meningkatkan Hasil Belajar Pendidikan Kewarganegaraan Siswa Kelas IV SD Negeri 016 Bangkinang Kota. Jurnal Basicedu, 1(1), 21-30. Https://Doi.Org/10.31004/Basicedu.V1i1.149 
1348 Pengembangan Media Pembelajaran IPA dengan Menggunakan Media "Rumah Eksis"di Sekolah Dasar - Vivi Herawati

DOI: https://doi.org/10.31004/basicedu.v6i1.2297

Annisa, N., \& Simbolon, N. (2018). Pengembangan Media Pembelajaran Interaktif Ipa Berbasis Model Pembelajaran Guided Inquiry Pada Materi Gaya Di Kelas Iv Sd Negeri 101776 Sampali. School Education Journal Pgsd Fip Unimed, 8(2), 217-229. Https://Doi.Org/10.24114/Sejpgsd.V8i2.10199

Aquami, A., Afandi, M., \& Sairi, A. P. (2019). Pengembangan Media Pembelajaran Berbasis Ict Menggunakan Macromedia Flash Pada Mata Pelajaran Ipa Mi/Sd. Journal AL-MUDARRIS, 2(1), 53. Https://Doi.Org/10.32478/Al-Mudarris.V2i1.194

Chika Pratama, B. (2019). Model Pembelajaran Two Stay Two Stray Berbantu Media Puzzle Terhadap Hasil Belajar Ditinjau Dari Gaya Belajar Siswa. Jurnal Penelitian Dan Pengembangan Pendidikan, 3(2), 84. Https://Doi.Org/10.23887/Jppp.V3i2.17382

Dolong, H. M. J. (2016). Teknik Analisis Dalam Komponen Pembelajaran. Jurnal UIN Alauddin, 5(2), $293-$ 300.

Isdayanti, Nulhakim, L., \& Syachruroji, A. (2020). Pengembangan Media Pembelajaran Audio Visual Berbasis Adobe Flash Pada Materi Daur Hidup Hewan. Jurnal Ilmiah Pendidikan Dan Pembelajaran, 4(2), 390-406.

Khoiriyah, E., \& Sari, E. Y. (2018). Pengembangan Media Pembelajaran Pop-Up Book Pada Mata Pelajaran Ipa Kelas Iii Sdn 3 Junjung Kecamatan Suymbergempol Kabupaten Tulungagung. Jurnal Bidang Pendidikan Dasar, 2(2), 22-32. Https://Doi.Org/10.21067/Jbpd.V2i2.2495

Koriaty, S., \& Agustani, M. D. (2016). Pengembangan Model Pembelajaran Game Edukasi Untuk Meningkatkan Minat Siswa Kelas X TKL SMK Negeri 7 Pontianak. Jurnal Edukasi, 14(2), 277-288.

Lado, D. K., \& Rosanensi, M. (2020). Media Pembelajaran Pengenalan Metamorfosis Sempurna Dan Tidak Sempurna Menggunakan Augmented Reality. Jurnal SASAK : Desain Visual Dan Komunikasi, 2(1), 110. Https://Doi.Org/10.30812/Sasak.V2i1.752

Masturah, E. D., Mahadewi, L. P. P., \& ... (2018). Pengembangan Media Pembelajaran Pop-Up Book Pada Mata Pelajaran IPA Kelas III Sekolah Dasar. Jurnal EDUTECH Univrsitas Pendidikan Ganesha, 6(2), 212-221. Https://Ejournal.Undiksha.Ac.Id/Index.Php/JEU/Article/View/20294

NURDIANA, F. (2018). Pengembangan Media Video Animasi Tentang Siklus Hidup Hewan Dengan Metamorfosis Bagi Siswa Kelas Iv Sekolah Dasar. Jurnal Mahasiswa Teknologi Pendidikan, 9(2).

Peprizal, \& Syah, N. (2020). Pengembangan Media Pembelajaran Berbasis Web Pada Mata Kuliah Fisika Modern. Jurnal Ilmiah Pendidikan Dan Pembelajaran, 4(3), 455-467.

Http://Repository.Untad.Ac.Id/3668/

Prilliza, M. D., Lestari, N., Merta, I. W., \& Artayasa, I. P. (2020). Efektivitas Penerapan Model Discovery Learning Terhadap Hasil Belajar IPA. Jurnal Pijar Mipa, 15(2), 130. Https://Doi.Org/10.29303/Jpm.V15i2.1544

Purnama, R. P., \& Marsudi. (2017). Pengembangan Media Pembelajaran IPA Materi Metamorfosis Berbentuk Video Animasi Dua Dimensi Pada SDI Little Camel Mojokerto. Jurnal Seni Rupa, 5(3), 433-454.

Qistina, M., Alpusari, M., Noviana, E., \& Hermita, N. (2019). Pengembangan Multimedia Interaktif Mata Pelajaran Ipa Kelas Ivc Sd Negeri 034 Taraibangun Kabupaten Kampar. Primary: Jurnal Pendidikan Guru Sekolah Dasar, 8(2), 148. Https://Doi.Org/10.33578/Jpfkip.V8i2.7649

Rawung, I. Y. (2019). Strategi Pembelajaran Aktif Bagi Guru Sekolah Dasar Di SD GKST II Poso Kota Utara. Jurnal Strategi Pembelajaran Aktif Bagi Guru Sekolah Dasar, 1(1), 49-55.

Suryani, E., Ws, R., \& Nugraha, A. (2018). Pengaruh Model Example Non Example Terhadap Hasil Belajar Pada Materi Sumber Daya Alam Di SD. PEDADIDAKTIKA: Jurnal Ilmiah Pendidikan Guru Sekolah Dasar, 5(1), 100-108.

Tarwiti, C., \& Wijayanti, A. (2018). Pengembangan Media Kotak Ajaib Pada Mata Pelajaran IPA Materi Pesawat Sederhana Siswa Kelas V Sekolah Dasar. Jurnal Sekolah (JS), 2(4), 308-314. 
1349 Pengembangan Media Pembelajaran IPA dengan Menggunakan Media "Rumah Eksis"di Sekolah Dasar - Vivi Herawati

DOI: https://doi.org/10.31004/basicedu.v6il.2297

Veronica, I., Whyu Pusari, R., \& Setiawardana, M. Y. (2018). Pengembangan Media Scrapbook Pada Pembelajaran Ipa. Jurnal Imiah Pendidikan Dan Pembelajaran, 2(3), 258.

Https://Doi.Org/10.23887/Jipp.V2i3.16222

Wahyu Ningtiyas, T., \& Mei, N. (2019). Pengembangan Media Pop-Up Book Untuk Mata Pelajaran Ipa Bab Siklus Air Dan Peristiwa. Jurnal Kajian Teknologi Pendidikan, 2(2), 115-120.

Widiana, I. W., Rendra, N. T., \& Wulantari, N. W. (2019). Media Pembelajaran Puzzle Untuk Meningkatkan Hasil Belajar Siswa Kelas Iv Pada Kompetensi Pengetahuan Ipa. Indonesian Journal Of Educational Research And Review, 2(3), 354. Https://Doi.Org/10.23887/Ijerr.V2i3.22563 